\title{
PELATIHAN VLOG WARGA RW 09 KELURAHAN KEMBANGAN UTARA KECAMATAN KEMBANGAN UTARA JAKARTA BARAT
}

\author{
1)Yoyoh Hereyah, 2), Hendri Wierfan, 3). Marie Muhammad \\ Program Studi Ilmu Komunikasi, Fakultas Ilmu Komunikasi, Universitas Mercu Buana Jakarta \\ Email : yoyoh.hereyah@mercubuana.ac.id, hendriwirfan@gmail.com, \\ mariemuhammad@gmail.com
}

\begin{abstract}
ABSTRAK
Membuat vlog di era disrupstion ini sangat penting bagi siapa saja, termasuk bagi warga desa dan kelurahan yang ingin menginformasikan kegiatan dan program-program desanya dalam bentuk video yang menarik. Banyak kegunaan membuat blog di era kini, selain bisa memperkaya kemampuan kita di sisi yang lain kemampuan inni bisa diterapkan dalam kehidupan sehari-hari terkait dengan penyampaian pesan komunikasi. Kehidupan ibu ibu dan bapak di tegah keluarga, bisa menjadi bahan yang tidak ada habisnya untuk membuat Vlog. Vlog berasal dari dua kata yakni 'video' dan 'blog'. Apa itu video? Video adalah teknologi untuk menangkap, merekam, memproses, mentransmisikan dan menata ulang gambar bergerak. Lalu apa itu Blog? Blog adalah catatan pribadi secara online yang sering diperbarui dan didistribusikan ke masyarakat umum. Nah, kalau begitu apa itu Vlog? Jadi, Vlog adalah catatan pribadi dalam bentuk video yang diperbarui dan didistribusikan secara umum. Lebih lengkapnya, Vlog ini termasuk suatu bentuk kegiatan blogging dengan menggunakan medium video di atas sumber media utamanya yakni penggunaan teks atau audio. Kegiatan ini di harapkan memberikan pemahaman yang mendalam tentang teknik membuat vlog yang memberikan manfaat bagi warga RW 09 Kelurahan Kembangan Utara Kecamatan Kembangan Utara Jakarta Barat, sehingga diharapkan manfaat yang didapat memberi dampak yang positif bagi mereka, dengan mampu membuat vlog maka di tengah keluarga bisa menghasilkan tambahan baru dari hasil pendapatan iklan yang masuk, disamping menambah kemampuan melakukan literasi informasi
\end{abstract}

Kata Kunci : Vlog, RPTRA, VideoBlogger, Pengabdian Masyarakat

\section{PENDAHULUAN}

\subsection{LATAR BELAKANG}

Membuat vlog di era disrupstion ini sangat penting bagi siapa saja, termasuk bagi warga desa dan kelurahan yang ingin menginformasikan kegiatan dan program- program desanya dalam bentuk video yang menarik. Banyak kegunaan membuat blog di era kini, selain bisa memperkaya kemampuan kita di sisi yang lain kemampuan inni bisa diterapkan dalam 
kehidupan sehari-hari terkait dengan penyampaian pesan komunikasi.

Kehidupan ibu ibu dan bapak di tegah keluarga, bisa menjadi bahan yang tidak ada habisnya untuk membuat Vlog. Vlog berasal dari dua kata yakni 'video' dan 'blog'. Apa itu video? Video adalah teknologi untuk menangkap, merekam, memproses, mentransmisikan dan menata ulang gambar bergerak. Lalu apa itu Blog? Blog adalah catatan pribadi secara online yang sering diperbarui dan didistribusikan ke masyarakat umum. Nah, kalau begitu apa itu Vlog? Jadi, Vlog adalah catatan pribadi dalam bentuk video yang diperbarui dan didistribusikan secara umum. Lebih lengkapnya, Vlog ini termasuk suatu bentuk kegiatan blogging dengan menggunakan medium video di atas sumber media utamanya yakni penggunaan teks atau audio

Kondisi di atas, sangat cocok sekali untuk diterapkan bagi warga Kelurahan Kembangan Utara, khususnya warga RT 9. Kontur dan kondisi wilayah yang padat penduduk, tentunya memiliki banyak persoalan dan permasalahan yang bisa dipecahkan dengan pemberian informasi yang benar. Dan salah satu sarana yang paling tepat dan pas adalah menggunakan
Vlog. Maka dari itu pelatihan pembuatan vlog itu penting bagi masyarakat sasaran.

\subsection{Justifikasi dan Sasaran}

Kegiatan ini di harapkan memberikan pemahaman yang mendalam tentang teknik membuat vlog yang memberikan manfaat bagi warga RW 09 Kelurahan Kembangan Utara Kecamatan Kembangan Utara Jakarta Barat, sehingga diharapkan manfaat yang didapat memberi dampak yang positif bagi mereka, dengan mampu membuat vlog maka di tengah keluarga bisa menghasilkan tambahan baru dari hasil pendapatan iklan yang masuk, disamping menambah kemampuan melakukan literasi informasi.

Selain manfaat di atas, tujuan dilaksanakan pelatihan pembuatan vlog ini adalah untuk membuka wawasan/pengetahuan dan memberikan bekal kepada warga RW 09 untuk secara kritis memanfaat kemampuan menggunakan media sosial dan pemanfaatan internet yang dapat memberikan nilai ekonomi bagi mereka dengan membuat Dengan demikian diharapkan nantinya warga RW 09 melakukvlog ini secara professional.

\subsection{Identifikasi Masalah}

Beragamnya informasi yang terkadang tidak tertata dengan baik di tengah masyarakat Ekonomi, Sosial, dan Budaya $\quad 1206$ 
bisa mengganggu tatanan kemasyarakatan yang ada. Teknik pembuatan vlog ini sebenarnya alternatif bagi masyarakat di tengah perkotaan yang bisa memanfaatkan waktu dan kemampuannya untuk menciptakan video blogging yang bermanfaat bagi masyarakat. Contoh yang paling gampang adalah warga masyarakat bisa membuat vlog tentang bagaimana saat mereka memasak, membuat kue atau kegiatan lainnya yang bermanfaat buat orang lain.

Berdasarkan latar belakang dan situasi di atas, maka identifikasi masalahnya adalah sebagai berikut; "Bagaimana masyarakat terutama terutama ibu ibu warga RT 9 Kelurahan Kembangan Utara kecamatan Kembangan Utara Jakarta Barat memanfaatkan internet danmembuat video blogging di wilayahnya.

\subsection{Relevansi}

Dilaksanakan pelatihan PEMBUATAN VLOG diharapkan bermanfaat sebagai berikut :

- Dengan pelatihan vlog ini masyakat terutama warga ibu ibu RT 9 Kelurahan Kembangan Utara akan memiliki pemahaman yang bagus tentang pentingnya memanfaatkan internet secara baik

- Peserta mampu memilih topik pembuatan vlog yang cocok dengan wilayah / tempat tinggalnya,

- Peserta mampu memilih dan membedakan format pembuatan vlog yang disesuaikan dengan platform sosial media yang hendak digunakan sebagai saluran distribusinya

- Peserta mampu memilih aplikasi video yang seperti apa yanng sesuai dengan topik

- Peserta mampu mempraktekan teknik pembuatan vlog sesuai dengan arahan dan panduan.

- Pada akhirnya workshop pembuatan vlog ini, diharapkan mampu memberikan pemberdayaan bagi peserta untuk membangun ekonomi kreatif bagi diri dan wilayahnya serta menjadi agent of change pemberdayaan diri dan wilayahnya.

\section{METODE}

\subsection{Pre Test}

Mengingat peserta adalah ibu ibu warga kelurahan, khususnya warga RT 9, kebanyakan peserta adalah ibu ibu rumah tangga, maka kegiatan 
diarahkan untuk memberikan pemberdayaan bagi peserta, bentuk yang dilakukan selain menjelaskan secara detil, juga praktek atau demonstrasi langsung dihadapan peserta, selain itu selama beberapa minggu, juga melakukan pendampingan dan monitoring untuk melihat keberhasilan pelatihan pembuatan vlog.

\subsection{Pengarahan}

Target dari program pengabdian masyarakat dengan tema pelatihan pembuatan vlog ini adalah warga Kelurahan Kembangan Utara, khususnya pemuda dan orang dewasa warga RT 9, yang dibagi perkelompok, masing masing kelompok terdiri dari 4 atau 5 anggota binaan.

\subsection{Pelaksanaan}

Dalam pengabdian ini akan diisi oleh pemateri :
a. Yoyoh Hereyah
b. Mar'I Muhammad
c. Hendri Wirfan

Untuk menjelaskan berbagai hal terkait dengan Teknik pembuatan Vlog di atas, maka pelatihan ini dilakukan selama tiga minggu dengan menggunakan metode sebagai berikut: Ceramah
Metode ini dipilih untuk menyampaikan konsep-konsep yang penting dalam menjelaskan apa itu vlog, nagaimana Teknik pembuatan vlog, memilih aplikasi video yang sesuai, memilih topik, talen, memilih pesan yang hendak disampaikan, tata editing video dan melakukan proses pasca produksi hingga menghasilkan kualitas video vlog yang sesuai dengan yang kita harapkan.

\section{Demonstrasi}

Metode ini dipilih untuk menunjukkan contoh-contoh teknik pembuatan vlog, menentukan topik yang sesuai, menyajikan contoh vlog bagus yang bisa ditiru dan dimodifikasi sesuai degan kebutuhan Kemudian melakukan praktik langsung membuat vlog yang sesuai dengan kebutuhan

\section{Latihan dan Tanya Jawab}

Metode ini digunakan untuk memperjelas w. awasan dan pemahaman peserta, dan meminimalisir kesalahan mempraktekkan pembuatan vlog.

\subsection{Post Test}

Ekonomi, Sosial, dan Budaya 
Kegiatan Pengabdian Masyarakat dilaksanakan dengan ceramah, demonstrasi, dan latihan serta tanya jawab, ini dilaksanakan setelah program pengabdian masyarakat dilangsungkan.

\section{HASIL DAN PEMBAHASAN}

\subsection{Hasil}

\begin{tabular}{|c|c|c|}
\hline No & Jenis Luaran & Indikator Capaian \\
\hline 1 & Publikasi ilmiah dijurnal/prosiding 1) & Draf \\
\hline 2 & Publikasi pada media massa 2) & Draf \\
\hline 3 & Peningkatan pendapatan bagi warga & ada \\
\hline 4 & Peningkatan kualitas dan kuantitas produk 3) & Tidak ada \\
\hline 5 & Peningkatan pemahaman dan keterampilan masyarakat 3) & Draf \\
\hline 6 & $\begin{array}{lll}\text { Peningkatan ketentraman/kesehatan } & \text { masyarakat } & \text { (mitra } \\
\text { masyarakat umum) 3) } & & \end{array}$ & Ada \\
\hline 7 & Jasa, model, rekayasa sosial, sistem produl/barang 4) & Tidak ada \\
\hline 8 & $\begin{array}{l}\text { Hak kekayaan intelektual (paten, paten sederhana, hak cipta, } \\
\text { merek dagang 5) }\end{array}$ & Tidak ada \\
\hline 9 & Buku ajar 6) & Tidak ada \\
\hline
\end{tabular}

Kegiatan ini di harapkan memberikan pemahaman yang mendalam tentang teknik pembuatan vlog yang memberikan manfaat bagi warga RW 09 Kelurahan Kembangan Utara Kecamatan Kembangan Utara Jakarta Barat, sehingga diharapkan manfaat yang didapat memberi dampak yang positif bagi mereka, dengan mampu membuat vlog maka di tengah keluarga bisa menghasilkan tambahan baru dari hasil pendapatan iklan yang masuk, disamping menambah kemampuan melakukan literasi informasi.

Selain manfaat di atas, tujuan dilaksanakan pelatihan pembuatan vlog ini adalah untuk membuka wawasan/pengetahuan dan memberikan bekal kepada warga RW 09 untuk secara kritis memanfaat kemampuan menggunakan media sosial dan pemanfaatan internet yang dapat memberikan nilai ekonomi bagi mereka dengan membuat Dengan demikian diharapkan nantinya warga RW 09 melakukan video vlog ini secara professional.

\subsection{Pembahasan}

Kegiatan dilaksanakan pada tanggal 31 Januari 2019 , yang diikuti oleh ibu ibu warga kelurahan Meruya Utara Kecamatan Kembangan, Bertempat di Aula RPTRA kelurahan Meruya Utara, workshop di buka oleh Lurah Meruya Utara, dilanjutkan oleh Ketua PIC Pengabdian Masyarakat Fakultas Ilmu Komunikasi, Ibu Anindita, S.Pd, M.Ikom.

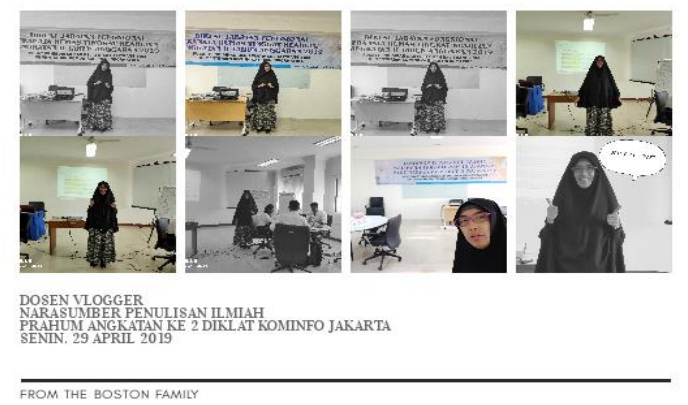

Setelah sambutan pembukaan, workshop dilanjutkan dengan pemaparan materi, demonstrasi cara pembuatan Vlog. Peserta di bawah mentor masing masing, dipandu untuk mempraktekkannya, dalam hal ini, Ekonomi, Sosial, dan Budaya 
Mentor adalah Mahasiswa Prodi Advertising and Marketing Communication Digital . Selain itu, peserta melakukan liputan di sekitar RPTRA Kecapi, mensyuting, mengambil gambar, melakukan wawancara dan mengumpulkan hasil gambar, lalu mengolah dan mengedit karya gambar tersebut dipandu oleh Mentor. Masing masing peserta, mengambil gambar dengan HP yang mereka miliki dan merekam moment di sekitar RPTRA Kecapi yang nantinya digunakan sebagai data based pembuatan Vlog peserta., Mentor memandu dan mengarahkan peserta untuk mengambil gambar dan merekamnya secara benar.

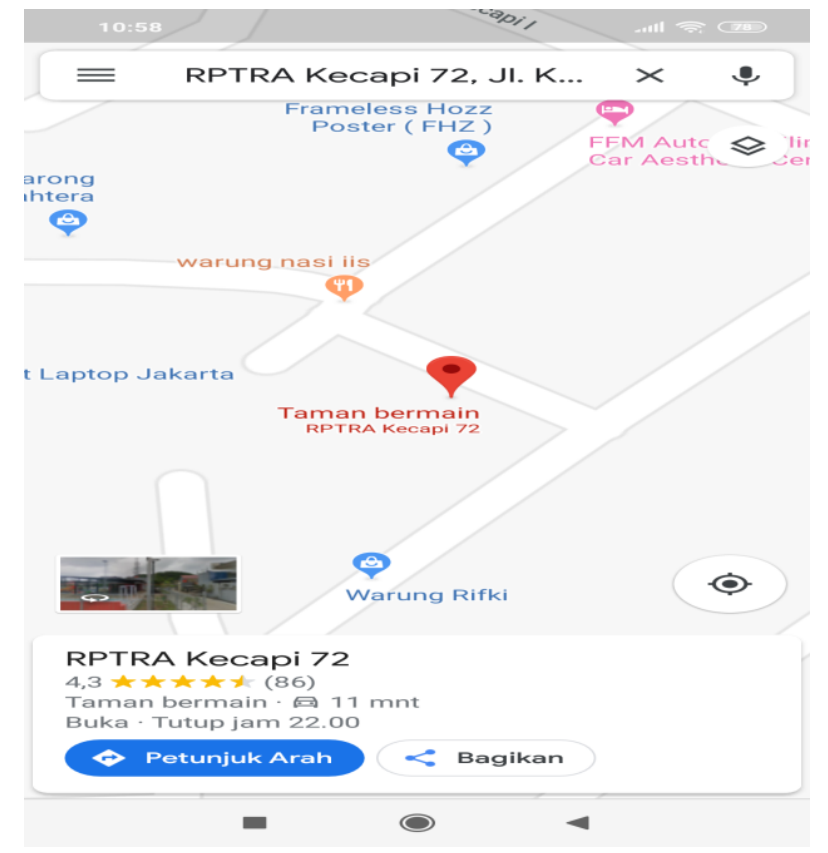

HP peserta dilengkapi dengan aplikasi Videoshow yang dapat mereka download di Ap Store atau di Google Play, Langkah
Langkah merekam gambar, mengedit hingga menghasilkan sebuah karya Vlog dipandu langsung dengan seksama oleh Mentor.

Hasil Karya peserta diupload diberbagai Platform media social, seperti FaceBook, You Tube atau Group Whats Up yang dimiliki masing masing peserta.

\section{KESIMPULAN DAN SARAN}

\subsection{KESIMPULAN}

literasi media dan informasi menjadi sebuah keharusan diberikan kepada warga untuk memberikan pemahaman penggunaan media yang baik terutama dalam pembuatan Vlog. Warga mendapatkan pemahaman informasi yang benar tentang pembuatan vlog agar mudah merekam dan mempublikasikan melalui youtube dan platform media social lainnya dan memberikan pemberdayaan untuk mempublikasikan kegiatan kegiatan di RPTRA Kecapi , metode pengajaran interaktif yang diterapkan membuat peserta mudah memahami materi dan fun, sehingga pesan yang diinginkan tersampaikan kepada mereka.

4.2. saran

kegiatan literasi media dan informasi dan pembuatan vlog perlu dilakukan 
kembali, memgingat perkembangan media dan konten yang masif setiap hari masuk dalam ruang maya, menjadi promosi bagi UMB, khususnya fakultas ilmu komunikasi, kegiatan bisa dilakukan simultan dalam beberapa waktu untuk dapat melihat hasil yang lebih optimal bagi peserta.

\section{DAFTAR PUSTAKA}

https://

http://www.kaiamedia.com/pengertianvlog 